\title{
THE METABOLISM OF $\left[{ }^{14} \mathrm{C}\right]$-DEBRISOQUINE IN MAN
}

\author{
J.R. IDLE, A. MAHGOUB, M.M. ANGELO, L.G. DRING, \\ R. LANCASTER \& R.L. SMITH \\ Department of Biochemical and Experimental Pharmacology, \\ St Mary's Hospital Medical School, Paddington, London W2 1PG
}

1 The synthesis of $\left[{ }^{14} \mathrm{C}\right]$-debrisoquine hydrochloride and 4-hydroxy-debrisoquine sulphate is described.

2 The metabolic fate and excretion profile in both urine and faeces of ${ }^{14} \mathrm{C}$-labelled debrisoquine was studied in five healthy human subjects.

3 Investigations showed that the drug is well-absorbed after a single oral dose of $32 \mathrm{mg}$ and quantitatively eliminated from the body within three days.

4 4-Hydroxy-debrisoquine is the major metabolite of debrisoquine, although significant amounts of 5-,6-, 7- and 8-hydroxy-debrisoquine are also formed.

5 Electron-capture gas chromatography is a useful method for measuring debrisoquine and its five hydroxylated metabolites in urine at the pg level.

\section{Introduction}

Debrisoquine was first introduced into the U.K. as an orally active antihypertensive agent in 1966 (see Athanassiadis, Cranston, Juel-Jensen \& Oliver, 1966; Kitchin \& Turner, 1966; Editorial, 1966). Chemically, debrisoquine is described as 3,4-dihydro$2-(1 H)$-isoquinoline-carboxamidine and is related structurally and pharmacologically to other guanidine based antihypertensives such as bethanidine and guanethidine.

Recent studies have shown that debrisoquine is metabolized in the body but that the extent to which this occurs is mainly genetically determined (Mahgoub, Idle, Dring, Lancaster \& Smith, 1977). Furthermore, responsiveness to the drug is influenced by metabolic status since subjects who poorly metabolize the drug are much more sensitive to the hypotensive effects than those who extensively metabolize the drug (Idle, Mahgoub, Lancaster \& Smith, 1978). Because of the important relationship between genetically determined ability to metabolize the drug and responsiveness it became important to define as fully as possible the qualitative and quantitative aspects of the metabolism of the drug in man.

Earlier studies have shown that the drug can undergo metabolism along two pathways, namely oxidation of the alicyclic and aromatic ring structures and by ring cleavage to give two acidic metabolites, namely, 2-(guanidinoethyl)benzoic acid and 2(guanidinomethyl)phenyl acetic acid (Allen, East, Francis \& Haigh, 1975; Allen, Brown \& Marten, 1976; Angelo, Dring, Lancaster, Latham \& Smith,
1975). In this paper we describe the qualitative and quantitative aspects of the metabolism and elimination of orally administered debrisoquine in five healthy male volunteers. Part of this work has already been presented as a preliminary communication (Angelo, Dring, Idle, Lancaster, Mahgoub \& Smith, 1977).

\section{Methods}

Synthesis of 3,4-dihydro-2-(1H)-isoquinoline $\left[{ }^{14} \mathrm{C}\right]$ carboxamidine hydrochloride $\left(\left[{ }^{14} \mathrm{C}\right]\right.$-debrisoquine $)$

$\left[{ }^{14} \mathrm{C}\right]$-Cyanamide was prepared as described by Graff, Engelman, Gillespie \& Graff (1951). A solution of potassium $\left[{ }^{14} \mathrm{C}\right]$-cyanide $(1.13 \mathrm{mg}, 1 \mathrm{mCi})$ (The Radiochemical Centre, Amersham, Bucks, U.K.) and non-radioactive potassium cyanide $(649 \mathrm{mg})$ in water $(6.5 \mathrm{ml})$ was added over a $15 \mathrm{~min}$ period to a stirred and cooled $\left(0^{\circ} \mathrm{C}\right)$ mixture of bromine $(0.5 \mathrm{ml})$ and water $(7.0 \mathrm{ml})$. After $15 \mathrm{~min}$, the pale yellow solution was extracted with diethyl ether $(3 \times 10 \mathrm{ml})$ and the bulked extracts dried over anhydrous sodium sulphate for $3 \mathrm{~h}$. The ethereal solution was then treated, without the removal of the sodium sulphate, with a solution of ammonia in methanol $(2.9 \mathrm{M}, 5 \mathrm{ml})$. Ammonium bromide precipitated and the mixture was then left overnight at $0^{\circ} \mathrm{C}$ to complete the reaction. The solids were filtered and the solvent removed in a rotary evaporator. The oily residue was dried in vacuo over phosphorus pentoxide for $20 \mathrm{~h}$, triturated with dry ether and the small amount of ammonium bromide 
that precipitated, filtered. On evaporation, the filtrate yielded $368 \mathrm{mg}$ crystalline $\left[{ }^{14} \mathrm{C}\right]$-cyanamide.

The next step was a modification of the method of Wenner (1965). $\left[{ }^{14} \mathrm{C}\right]$-Cyanamide $(368 \mathrm{mg})$ and 1,2,3,4-tetrahydroisoquinoline hydrochloride $(1.56 \mathrm{~g})$, suspended in toluene $(8 \mathrm{ml})$, were then refluxed together for $6 \mathrm{~h}$. After 2-3 h an extremely viscous lower phase was apparent. After cooling, and allowing to stand for $15 \mathrm{~h}$, the upper toluene layer was decanted and the lower glass-like layer dissolved in ethanol $(2 \mathrm{ml})$ and the solution cooled in an ice-bath. The addition of acetone $(5 \mathrm{ml})$ gave a crystalline solid which was re-crystallized twice from ethanol to give $576 \mathrm{mg}$ 3,4-dihydro-2-(1H)-isoquinoline $\left[{ }^{14} \mathrm{C}\right]-$ carboxamidine hydrochloride (specific activity 0.50 $\mu \mathrm{Ci} / \mathrm{mg}$ ), m.p. $176-179^{\circ} \mathrm{C}$ (Wenner, 1965 quotes $179-181^{\circ} \mathrm{C}$ ). The radiochemical yield was $28.8 \%$, calculated on the potassium $\left[{ }^{14} \mathrm{C}\right]$-cyanide. The radiochemical purity was determined by reverse isotope dilution and paper chromatography in solvent $\mathbf{A}$ followed by radiochromatogram scanning and found to be $>99 \%$.

Synthesis of 4-hydroxy-3,4-dihydro-2-(1H)-isoquinoline carboxamidine sulphate (4-hydroxydebrisoquine sulphate)

2-(1'-Hydroxy-2'-nitroethyl)-benzaldehyde lactol $\left(2.93 \mathrm{~g} ;\right.$ m.p. $120-122^{\circ} \mathrm{C}$ dec.) was first synthesized by the method of Baer \& Achmatowicz (1964).

A solution of the lactol $(1.0 \mathrm{~g})$ in $50 \%$ acetic acid $(10 \mathrm{ml})$ was then hydrogenated for $2-3 \mathrm{~h}$ according to Nakao, Yura \& Ito (1966) in the presence of platinum dioxide $(40 \mathrm{mg})$ at a pressure of $280 \mathrm{kPa}$. The platinum dioxide was removed by filtration, the filtrate reduced to dryness in vacuo at $35^{\circ} \mathrm{C}$ and the resulting pale yellow oil washed with water $(2 \times 10 \mathrm{ml})$ to remove acetic acid. The residue was then taken up in the minimum volume of ethanol and treated with a slight excess of $\mathrm{HCl}$ in ethanol. The solution was evaporated to dryness and the residue taken up in ethanol $(20 \mathrm{ml})$ and further evaporated in vacuo to remove any remaining trace of acetic acid. The residue was re-crystallized from ethanol to give white crystals of 4-hydroxy-1,2,3,4-tetrahydroisoquinoline hydrochloride (458 mg) (m.p. $\left.196^{\circ} \mathrm{C}\right)$.

The final condensation step was performed by a modification of the method of Wenner (1965). A solution of 4-hydroxy-1,2,3,4-tetrahydroisoquinoline hydrochloride $(458 \mathrm{mg})$ in water $(10 \mathrm{ml})$ was made strongly basic by the addition of a few drops of $10 \mathrm{M}$ $\mathrm{NaOH}$ and the milky base liberated extracted with dichloromethane $(3 \times 10 \mathrm{ml})$. The bulked organic extracts were dried by filtration through Whatman Phase Separating Paper and the solvent removed by evaporation in vacuo. The pale yellow residue $(416 \mathrm{mg})$ was suspended in water $(2 \mathrm{ml})$ and then mixed with a solution of $S$-methylpseudothiourea sulphate $(435 \mathrm{mg})$ in water $(3 \mathrm{ml})$. The unstoppered reaction mixture was allowed to stand at room temperature in a fume cupboard for $16 \mathrm{~h}$, whence crystals of 4-hydroxy-3,4-dihydro-2-(1H)-isoquinoline carboxamidine sulphate (4-hydroxy-debrisoquine sulphate) began to separate. These were filtered to give $68 \mathrm{mg}$ of product which had m.p. $253-254^{\circ} \mathrm{C}$ without re-crystallization. It was characterized by comparison with an authentic sample (m.p. $253-254^{\circ} \mathrm{C}$ ) which was the gift of Roche Products Ltd., U.K. Both samples (in $\mathrm{KBr}$ discs) had identical infra-red spectra (Perkin-Elmer 1579) with strong absorptions at 3.0 $(\mathrm{O}-\mathrm{H}), 3.1(\mathrm{~N}-\mathrm{H}), 6.0(\mathrm{C}=\mathrm{N}), 6.3(\mathrm{C}=\mathrm{N})$ and 9.2 $(\mathrm{O}-\mathrm{H}) \mu \mathrm{m}$. The proton n.m.r. spectra (Bruker HFX 90) were also equivalent.

Synthesis of N-carbamoyl-1,2,3,4-tetrahydro-isoquinoline (debrisoquine urea analogue)

The method used was essentially that of Bamberger \& Dieckmann (1893). 1,2,3,4-tetrahydroisoquinoline hydrochloride $(1.68 \mathrm{~g})$ and potassium cyanate $(0.81 \mathrm{~g})$ were each dissolved separately in the minimum quantities of water. The two solutions were then mixed and allowed to stand at room temperature. Shiny white leaflets separated which were filtered and dried in vacuo. N-Carbamoyl-1,2,3,4-tetrahydroisoquinoline $(1.4 \mathrm{~g})$ had m.p. $169^{\circ} \mathrm{C}$ (Bamberger \& Dieckmann quote $169^{\circ} \mathrm{C}$ ).

\section{Other reference compounds}

3,4-Dihydro-2-( $1 H)$-isoquinoline carboxamidine (debrisoquine sulphate; Declinax) (m.p. $274-276^{\circ} \mathrm{C}$ ) and its phenolic derivatives, namely, 5- (m.p. 298-300 ${ }^{\circ} \mathrm{C}$ ), 6- (m.p. not determined), 7- (m.p. $303^{\circ} \mathrm{C} \mathrm{dec}$ ) and 8-hydroxy-debrisoquine (m.p. $302-304^{\circ} \mathrm{C}$ ) were a gift of Roche Products Ltd, U.K. 3,4-Dihydro-2-(1H)-isoquinoline carboxamidinoxime$p$-toluene sulphonate $(N$-hydroxy-debrisoquine m.p. $112-114^{\circ} \mathrm{C}$ ) was the gift of Sterling-Winthrop Research Institute, Rensselaer, N.Y., U.S.A.

\section{Human investigations}

For the ${ }^{14} \mathrm{C}$ studies, healthy normotensive adult male volunteers were given orally a mixture of debrisoquine sulphate $(30 \mathrm{mg})$ and $\left[{ }^{14} \mathrm{C}\right]$-debrisoquine hydrochloride (10 mg; $5 \mu \mathrm{Ci}$ ) (total drug equivalent to $31.7 \mathrm{mg}$ free base) as a solution in water or contained in gelatine capsules. In four investigations, urine was collected at $1,2,3,4,6,10,24,48$ and $72 \mathrm{~h}$ and faeces at 24,48 and $72 \mathrm{~h}$ post-dosing. In three other investigations, urine was simply collected up to $24 \mathrm{~h}$ and the samples bulked with no collection of stools. 
Determination of ${ }^{14} \mathrm{C}$ in urine and preliminary separation of metabolites

Radioactivity in urine fractions was determined by scintillation spectrometry (Packard models 3214, 3320 and 3385$)$ using an aliquot of urine $(0.1-1.0 \mathrm{ml})$ in a dioxane-based scintillant. Primary separation of ${ }^{14} \mathrm{C}$-labelled urinary metabolites was effected by paper chromatography. In certain cases, the urine samples were too dilute for chromatographic analysis and were concentrated as follows: the urine was initially concentrated by lyophylization and the solid residue leached with methanol $(20-100 \mathrm{ml})$. The methanol extract was then reduced to $1-2 \mathrm{ml}$ in vacuo and stored overnight at $-20^{\circ} \mathrm{C}$ to precipitate urea which was removed by filtration. The clear solution was evaporated to dryness in a rotary evaporator at $30^{\circ} \mathrm{C}$ and the residue re-dissolved in water. This aqueous fraction could then be applied to a column of Amberlite XAD-2 resin which had been pre-washed successively with acetone, methanol and water and then employed according to Mule, Bastos, Jukofsky \& Saffer (1971). The methanolic eluate from this procedure contained over $90 \%$ of the applied ${ }^{14} \mathrm{C}$. It was evaporated to dryness and the residue dissolved in the minimum quantity of methanol and the solution used for paper chromatography. The concentrated metabolite solutions were chromatographed on Whatman $3 \mathrm{~mm}$ paper and developed in solvent systems A and B. Prior to application all samples were adjusted to $\mathrm{pH} 2$ with $1 \mathrm{M} \mathrm{HCl}$ as this largely prevented the phenomenon of 'double-spotting'. Reference standards dissolved in blank urine were cochromatographed and located using the following spray reagents: (a) Sodium nitroprusside-hydrogen peroxide spray for guanidines (Hofmann \& Wünsch, 1958); a mixture of 5\% aqueous sodium nitroprusside $(2 \mathrm{ml}), 3 \%$ aqueous sodium hydroxide $(1 \mathrm{ml}), 3 \%$ aqueous hydrogen peroxide $(5 \mathrm{ml})$ and water $(20 \mathrm{ml})$. Guanidines gave coloured spots on a yellow background. (b) Diazotized 4-nitroaniline for phenols: 4-nitroaniline $(0.25 \mathrm{~g})$ was dissolved in $1 \mathrm{M} \mathrm{HCl}$ $(25 \mathrm{ml})$ and the solution diluted with ethanol $(25 \mathrm{ml})$. Sodium nitrite $(0.1 \mathrm{~g})$ was added to $10 \mathrm{ml}$ of this solution and the chromatograms sprayed. After drying, the chromatograms were re-sprayed with $0.5 \mathrm{M} \mathrm{NaOH}$ in ethanol (Wickström \& Salvesen, 1952). Phenolic metabolites (5-, 6-, 7- and 8-hydroxydebrisoquine) gave red spots. (c) 4-Dimethylaminobenzaldehyde (DMAB) for urea derivatives: DMAB $(0.5 \mathrm{~g})$ was dissolved in a mixture of $2 \mathrm{M} \mathrm{HCl}(50 \mathrm{ml})$ and ethanol $(50 \mathrm{ml}) . \mathrm{N}$-Carbamoyl-1,2,3,4-tetrahydroisoquinoline gave a canary yellow spot after standing for $12 \mathrm{~h}$

The $R_{\mathrm{F}}$ values and colour reactions of debrisoquine and its derivatives are shown in Table 1.

${ }^{14} \mathrm{C}$-Bands on the paper chromatograms were located by radiochromatogram scanning (Packard scanner, models 7200 and 7201). Further resolution, identification and quantitation of the resulting four radioactive bands occurring at $R_{\mathrm{F}} 0-0.14,0.24-0.43$, $0.43-0.61$, and $0.62-0.81$ in System $A$ is later described.

\section{Determination of ${ }^{14} \mathrm{C}$ in faeces}

All faecal samples were homogenized in 5 vol. of water and bleached prior to counting. Faecal homogenate $(20 \mathrm{ml})$ was adjusted to $\mathrm{pH} 10$ with $10 \mathrm{M}$ $\mathrm{NaOH}$ and an equal volume of hydrogen peroxide (100 vol) added. The mixture was left to stand at ambient temperature for 2 days, then neutralized. Bleached supernatant $(0.5 \mathrm{ml})$ was then counted like urine in liquid scintillant. No qualitative procedures were performed on the faecal homogenates.

Table 1 Paper chromatography of debrisoquine and its derivatives

Compound

Debrisoquine

4-hydroxy-debrisoquine

5-hydroxy-debrisoquine

6-hydroxy-debrisoquine

7-hydroxy-debrisoquine

8-hydroxy-debrisoquine

Debrisoquine $\boldsymbol{N}$-hydroxy derivative

Debrisoquine urea analogue
- $\mathrm{R}_{\mathrm{F}}$ in solvent

B

$\boldsymbol{A}$

0.73

0.28

0.58

0.57

0.57

0.58

0.75

0.81
0.47

0.33

0.25

0.22

0.22

0.22

0.78
Colour reactions with:

nitroprusside

diazotized

4-nitro-aniline

$D M A B$

None

None

Reddish brown

Reddish brown

Reddish brown

Reddish brown

None

None
None

None

None

None

None

None

None

Yellow

Whatman $3 \mathrm{~mm}$ paper was used. Solvent compositions were: A: butan-2-ol: formic acid: water (100:12:10 $\left.\mathrm{v} / \mathrm{v}^{+}\right)$and B: propan-2-ol: ammonia (sp. gr. 0.88): water (20:1:2 v/v).

- $R_{F}$ calculated from centre of the large diffuse spots.

+ Aged for 1 week. 


\section{Reverse isotope dilution for debrisoquine in urine}

Debrisoquine sulphate (approx. $1 \mathrm{~g}$ accurately weighed) was added to the urine sample to be analysed (containing $>150,000 \mathrm{~d} / \mathrm{min}$ ) and, where necessary, water added to facilitate the dissolution of the carrier. The solution was made strongly basic $(\mathrm{pH}>13)$ with $10 \mathrm{M} \mathrm{NaOH}$, saturated with sodium chloride and extracted with dichloromethane $(3 \times 2$ vol $)$. The pooled extract was dried by filtration through Whatman Phase Separating Paper and then evaporated to dryness in vacuo. The residue was then dissolved in the minimum volume of dry ethanol, and a slight excess of $\mathrm{HCl}$ in ethanol added. After adding a few drops of diethyl ether, precipitation of $\left[{ }^{14} \mathrm{C}\right]-$ debrisoquine hydrochloride occurred; the solid was filtered and re-crystallized to constant specific activity from ethanol (m.p. $\left.179-180^{\circ} \mathrm{C}\right)$.

\section{Isolation of metabolite fractions}

Concentrated methanolic eluates from XAD-2 columns (see above) were resolved into four major ${ }^{14} \mathrm{C}$ fractions by paper chromatography in system $A$ as described. The chromatographic bands were cut out and eluted separately by submergence in beakers containing methanol $(100 \mathrm{ml})$ for up to $2 \mathrm{~h}$. The methanol fractions were reduced to a small volume $(<1 \mathrm{ml})$ in vacuo and then further purified by t.l.c. using silica gel $60 \mathrm{~F}_{254}$ plates (E. Merck, Darmstadt, W. Germany) which had been washed with methanol.

After location of radioactivity by radiochromatogram scanning, the ${ }^{14} \mathrm{C}$ areas were scraped off the plate and eluted with methanol. The metabolites in the methanolic eluates were subsequently identified by gas-chromatography and by gas-chromatography-mass spectrometry (vide infra).

\section{Gas-chromatographic methods}

Gas chromatography was utilized both to identify and measure the various metabolites of debrisoquine in human urine. Two methods were applied: in the first, flame-ionization detection (f.i.d.) was used to identify debrisoquine and 4-hydroxydebrisoquine; in the second, electron-capture detection (e.c.d.) was used to both identify and quantitate debrisoquine and its hydroxylated metabolites, namely, 4-, 5-, 6-, 7- and 8hydroxy-debrisoquine.

\section{Flame-ionization detection (f.i.d.)}

Reference compounds, freeze-dried urinary extracts and isolated metabolite fractions in methanol were derivatized with acetylacetone according to Shemyakin, Ouchinnikov, Vinogradova, Feigina, Kiryushkin, Aldanuva, Alakhov, Lipkin \& Rosinov (1967) and
Vetter-Diechtl, Vetter, Richter \& Biemann (1968). This reaction converts debrisoquine and its derivatives to dimethylpyrimidine derivatives which are readily extracted by organic solvents and are volatile and therefore more amenable to gas-chromatography than their polar amidine precursors. To a solution of sample $(100 \mu \mathrm{g})$ in $50 \%$ saturated aqueous sodium bicarbonate $(0.2 \mathrm{ml})$ and methanol $(0.8 \mathrm{ml})$ was added freshly-distilled acetylacetone $(0.2 \mathrm{ml})$. After heating in a capped vial at $50^{\circ} \mathrm{C}$ for $48 \mathrm{~h}$, water $(4.8 \mathrm{ml})$ was added. The pH was adjusted to 8.5 with $2 \mathrm{M} \mathrm{NaOH}$ and the mixture extracted with chloroform $(3 \times 12 \mathrm{ml})$. Bulked extracts were reduced to dryness in vacuo and the residue dissolved in pyridine $(100 \mu \mathrm{l})$ for injection into the gas chromatograph or for further derivatization of phenolic groupings, with either N,O-bis(trimethylsilyl)-acetamide (BSA; Phase Separations Ltd, Queensferry, Flintshire, U.K.) or N,O-bis(trimethylsilyl)-trifluoroacetamide (BSTFA) $+1 \%$ trimethylchlorosilane (TMCS; Pierce Chemicals Co., Rockford, Ill., U.S.A.). Samples (1-2 $\mu$ l) were injected into a Hewlett Packard F\&M Scientific 402 gas chromatograph fitted with a 3\% OV-225 column (support phase: Chromosorb W, 100-120 mesh; length: $1.22 \mathrm{~m} ; 2 \mathrm{~mm}$ i.d.) and a flame-ionization detector; carrier gas was nitrogen with a flow rate of $28 \mathrm{ml} \mathrm{min}^{-1}$. Chromatograms were run isothermally at $200^{\circ} \mathrm{C}$ with the flame-ionization detector maintained at $250^{\circ} \mathrm{C}$.

\section{Electron-capture detection}

Debrisoquine and its hydroxylated metabolites in urine were converted to their bis-(trifluoromethyl)pyrimidine products by reaction with hexafluoroacetylacetone (HFAA) according to Erdmansky \& Goehl (1975). To urine $(100 \mu \mathrm{l})$ in a screw-cap septum vial was added $100 \mu \mathrm{l}$ water containing 7-methoxyguanoxan $(10 \mu \mathrm{g})$ (the gift of Pfizer Ltd, Sandwich, Kent, U.K.) as internal standard, $1 \mathrm{M}$ sodium bicarbonate $(100 \mu \mathrm{l})$, hexafluoroacetylacetone $(100 \mu \mathrm{l})$ and re-distilled benzene $(1 \mathrm{ml})$. The reaction vial was heated in an aluminium heating block at $100^{\circ} \mathrm{C}$ for $1 \mathrm{~h}$. The vial was then cooled and $3 \mathrm{M} \mathrm{NaOH}(5 \mathrm{ml})$ added to hydrolyse excess HFAA. The sample was vortexed, centrifuged and a portion of the benzene phase $(1 \mu l)$ injected into a Becker 417 gas chromatograph fitted with a tritium-scandium electron-capture detector $(75 \mathrm{mCi})$ and a $3 \%$ OV-1 column (support phase: Chromosorb W. HP, 80-100 mesh; length: $1.83 \mathrm{~m} ; 3 \mathrm{~mm}$ i.d.). Carrier gas was $5 \%$ argon in methane with a flow rate of $60 \mathrm{ml} \mathrm{min}^{-1}$. Chromatograms were run isothermally at $195^{\circ} \mathrm{C}$ with the electron-capture detector stabilized at $235^{\circ} \mathrm{C}$. Because this type of detector has a linear response only over a narrow concentration range, for debrisoquine, about $1-100 \mathrm{pg}$ on column, many samples had to be diluted and re-derivatized to bring them into the 


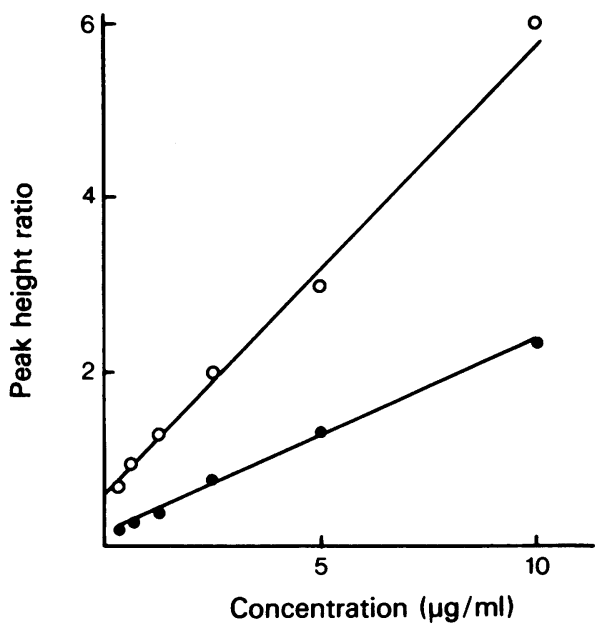

Figure 1 Calibration curves for debrisoquine (O) and 4-hydroxy-debrisoquine (O).

range of the calibration curve of concentration plotted against ratio of peak heights debrisoquine: internal standard. This assay measured debrisoquine and 4hydroxy-debrisoquine. To quantitate the phenolic metabolites, a solution of BSA (10\% in benzene; $50 \mu \mathrm{l})$ was added to an equal volume of the benzene layer from the derivatization reaction and the mixture shaken. An aliquot $(1 \mu \mathrm{l})$ of this solution was injected onto the column and the trimethylsilyl ethers of the phenols resolved with a flow rate of $30 \mathrm{ml} \mathrm{min}^{-1}$ and a column temperature of $160^{\circ} \mathrm{C}$. The retention times of the compounds relative to 7 -methoxyguanoxan were: debrisoquine, 0.19 ; 4-hydroxy-debrisoquine, 0.41 ; 5hydroxy-debrisoquine, 0.59; 6-hydroxy-debrisoquine, $0.75 ; \quad 7$-hydroxy-debrisoquine, $0.67 ; \quad 8$-hydroxy-

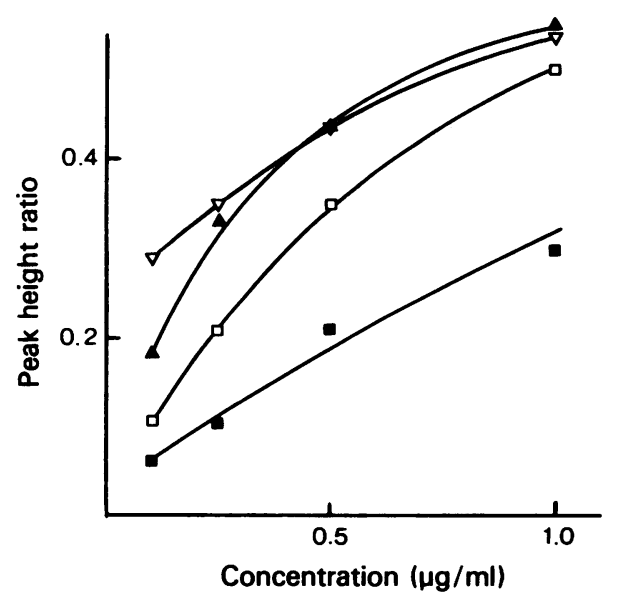

Figure 2 Calibration curves for 5- $(\nabla), 6-(\square), 7-(\square)$ and 8-hydroxy-debrisoquine (A). debrisoquine, 0.54. Calibration curves for debrisoquine and its five hydroxylated metabolites are shown in Figures 1 and 2. The standard deviation in peak height ratio across the full range of concentrations was less than $5 \%$ for all six curves.

\section{Gas chromatography — mass spectrometry}

Samples of lyophylized human urine derivatized with acetylacetone as described were analysed by gas chromatography-mass spectrometry (g.c.m.s.). A Varian MAT 311A mass spectrometer was used interfaced with a Varian Aerograph 1400 using a column of $3 \%$ OV-225 on Chromosorb $\mathrm{W}$ and programmed from $200^{\circ} \mathrm{C}$ to $270^{\circ} \mathrm{C}$ at $6^{\circ} \mathrm{C} \mathrm{min}^{-1}$. Helium was employed as carrier gas. Mass spectra were acquired on all peaks in the chromatogram and compared with those obtained from standards run similarly.

\section{Results}

Five human subjects were each given $\left[{ }^{14} \mathrm{C}\right]-$ debrisoquine orally at a dose equivalent to $32 \mathrm{mg}$ of the free base. Two of these volunteers were similarly re-investigated some months later. The data derived from these seven investigations is summarized in Table 2. The drug was well-absorbed, $72.0 \pm 5.3 \%$ ( \pm s.d.) of the ${ }^{14} \mathrm{C}$ being recovered in the urine within $24 \mathrm{~h}$. In four of the seven investigations, urine and faeces were collected up to $72 \mathrm{~h}$. The second and third day urines contained $8.9 \pm 3.2$ and $2.3 \pm 1.4 \%$ of the dose, and the first, second and third day faeces contained $4.6 \pm 7.2,2.8 \pm 1.2$ and $0.9 \pm 1.3 \%$ of the dose respectively. The total radioactivity excreted in the urine and faeces of four subjects in 3 days was thus $93.8 \pm 5.6 \%$ of the administered dose.

Radiochromatographic investigation of the $0-24 \mathrm{~h}$ urine revealed four ${ }^{14} \mathrm{C}$ bands of $R_{\mathrm{F}} 0-0.12$, $0.25-0.43,0.43-0.61,0.62-0.81$ in system A. A typical radiochromatogram scan of a paper run in system $A$ is shown in Figure 3. From their position on the chromatograms and colour reactions to the

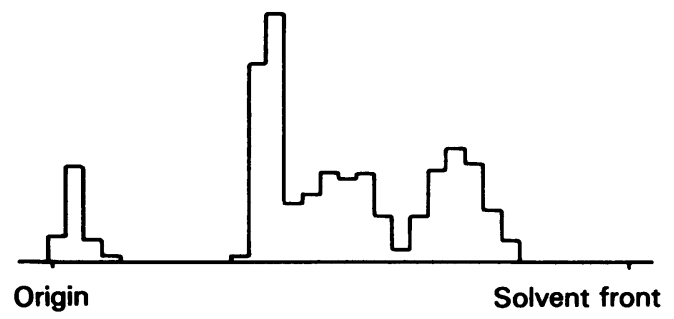

Figure 3 Typical radiochromatogram scan of urinary excretion products of $\left[{ }^{14} \mathrm{C}\right]$-debrisoquine indicating at least four major radiolabelled entities. 


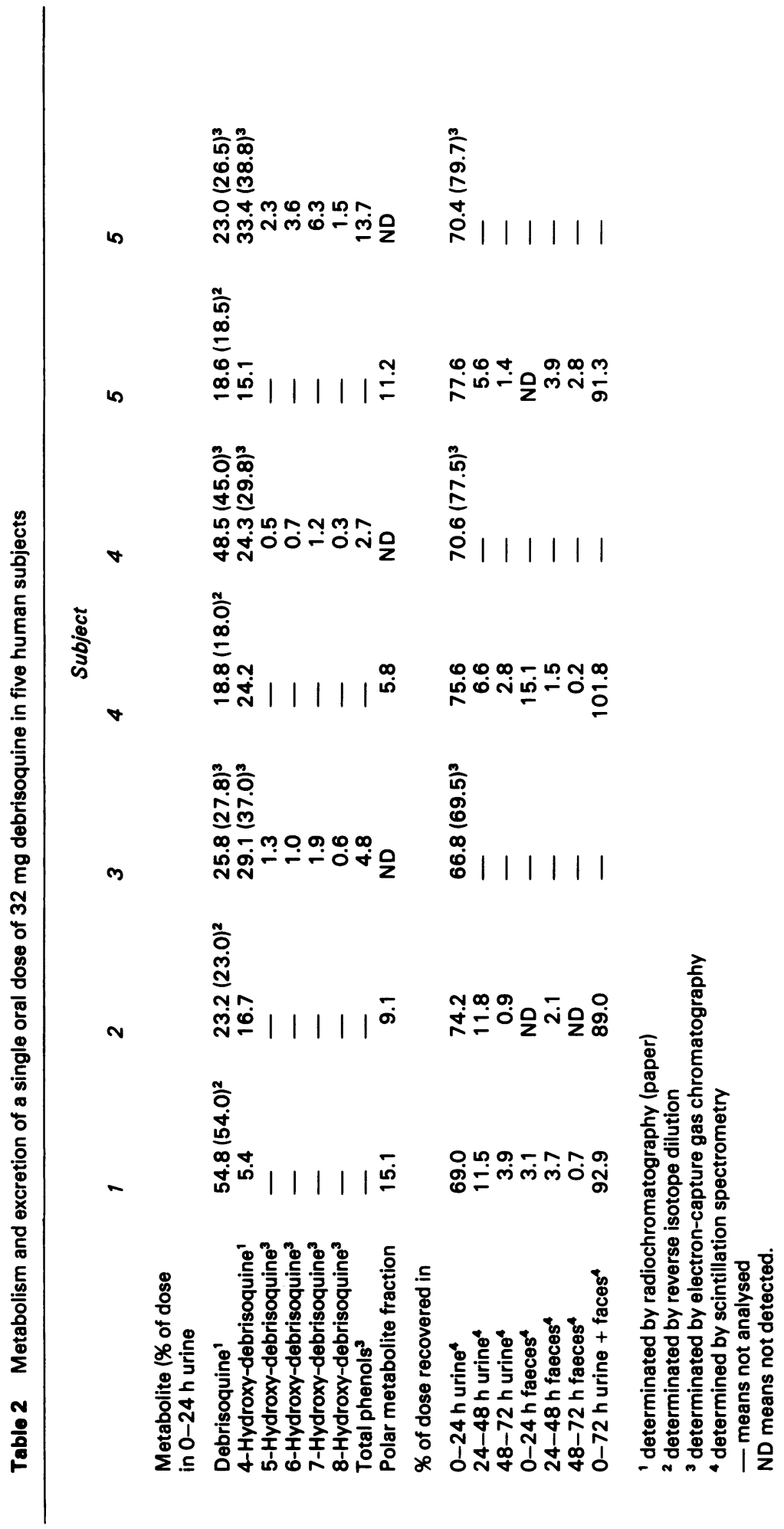




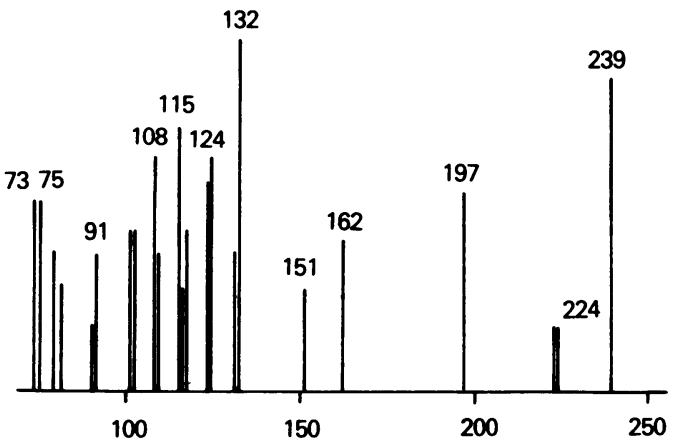

Figure 4 Mass spectrum of debrisoquine isolated from human urine, derivatized with acetylacetone (see text).

locating sprays (see Table 1), the bands were initially identified as debrisoquine $\left(R_{\mathrm{F}} 0.62-0.81\right)$, 4-hydroxydebrisoquine (0.25-0.43), a band corresponding to the phenolic metabolites 5-, 6-, 7- and 8-hydroxydebrisoquine $(0.43-0.61)$ which were unresolved on the paper chromatograms and a polar ${ }^{14} \mathrm{C}$ band $(0-0.12)$ which did not correspond to any of the reference compounds. Neither the $\mathrm{N}$-hydroxylated metabolite nor the urea analogue was detected by paper chromatography as urinary metabolites of debrisoquine. Confirmation and measurement of the various metabolites of debrisoquine is discussed hereafter.

\section{Debrisoquine}

The presence of the unchanged drug in urine was confirmed by gas chromatography on OV-225 (f.i. detection) and OV-1 (e.c. detection) and by g.c.m.s. In all three systems a peak $\left(R_{t} 4.9 \mathrm{~min}\right.$ on OV-225) occurred in the chromatogram after injection of derivatized urinary extracts at the same retention time as debrisoquine ( $R_{t} 4.9 \mathrm{~min}$ on OV-225). Furthermore, the mass spectrum obtained from this peak was identical for authentic debrisoquine (Figure 4). Urinary debrisoquine was quantitated by three procedures, good correspondence being found for the

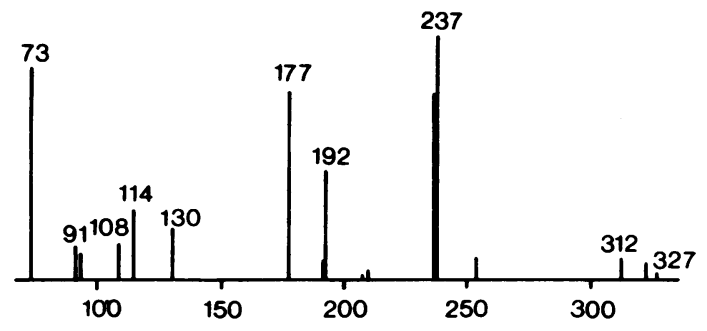

Figure 5 Mass spectrum of 4-hydroxydebrisoquine isolated from human urine, derivatized with acetylacetone (see text). three modes of assay (see Table 2). Firstly, the drug was quantitated by scintillation counting of the ${ }^{14} \mathrm{C}$ areas on paper chromatograms of urine samples, corresponding to debrisoquine (band of $R_{\mathrm{F}} 0.62-0.81$ in solvent A). Secondly, by reverse isotope dilution and thirdly by quantitative e.c.g.c. Unchanged drug was excreted in large and variable amounts by the five subjects studied; $30.4 \pm 14.9$ (range 18.6-54.8) \% of the dose of debrisoquine was found to be excreted unchanged in the $0-24 \mathrm{~h}$ urine.

\section{4-Hydroxy-debrisoquine}

The presence of 4-hydroxy-debrisoquine in urine and in eluates of paper chromatograms of urine samples was also confirmed by gas-chromatography and g.c.m.s. Both urine samples and eluates of metabolites derivatized with acetylacetone showed a peak $\left(\mathbf{R}_{t}\right.$ $7.3 \mathrm{~min}$ ) corresponding to 4-hydroxy-debrisoquine $\left(R_{t}\right.$ $7.4 \mathrm{~min}$ ) by gas chromatography on OV-225. The mass spectrum taken from this peak ivas also identical to that from the reference sample (Figure 5). 4Hydroxy-debrisoquine was quantitated by paper chromatography followed by radiochromatogram scanning and e.c.g.c. A poor correspondence was observed between two assays, the radiochromatographic assay consistently giving lower values than the g.c. method (see Table 2). Because 4-hydroxydebrisoquine was detected in the eluate of phenolic metabolites by e.c.g.c., it is obvious that this compound does not move as a single spot in this paper chromatographic system, thereby giving low estimates, when estimated by quantitative radiochromatogram scanning. The excretion of this metabolite as shown by radiochromatography shows a large inter-individual variation, $21.1 \pm 9.5 \%$ (5.4-33.4) of the dose excreted in the $0-24 \mathrm{~h}$ urine as 4-hydroxy-debrisoquine.

\section{5-, 6-, 7- and 8-Hydroxy-debrisoquine}

The ${ }^{14} \mathrm{C}$ band which eluted at $R_{\mathrm{F}} 0.43-0.61$ on paper in system $\mathrm{A}$, corresponded to these phenolic metabolites by $\boldsymbol{R}_{\mathrm{F}}$ values and also gave a strong positive reaction to diazotized 4-nitroaniline spray, indicating the presence of phenols. When this band was isolated, purified as described and derivatized with hexafluoroacetylacetone followed by BSA, peaks corresponding to debrisoquine, 4-, 5-, 6-, 7- and 8hydroxy-debrisoquine were seen (Figure 6). None of these peaks occurred in derivatized blank urine or in reagent blanks run on the gas chromatograph and were thus debrisoquine-related. This separation was used as the basis of an assay to quantitate 5-, 6-, 7and 8-hydroxy-debrisoquine. When the appropriate ${ }^{14} \mathrm{C}$ eluate was derivatized with acetylacetone and run on OV-225, peaks corresponding to all four phenols were also seen. The e.c.g.c. method affords a method 

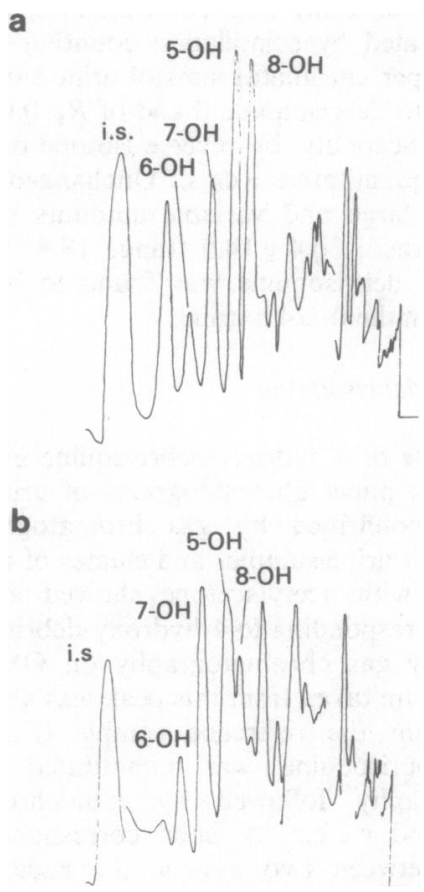

Figure 6 Gas-chromatographic separation of the phenolic metabolites of debrisoquine (see text). a) standards of the metabolites, b) metabolites extracted from human urine. i.s. 7-methoxyguanoxan.

of resolving and measuring the small amounts of these phenolic metabolites in urine. In the three urines which were analysed by this method, the phenols were relatively minor metabolites, comprising in total $7.1 \pm 5.8 \%(2.7-13.7)$ of the dose, the 7-hydroxylated compound being the most abundant phenol found. Incubations of urine with $\beta$-glucuronidase (Ketodase, Warner-Chilcott, Eastleigh, Hants., U.K. at pH 5) or sulphatase (Sigma Chemical Co., Kingston-uponThames, U.K. at pH 5) did not increase the amounts of debrisoquine, 4-hydroxy-debrisoquine or the phenolic metabolites indicating that these are excreted unconjugated in man.

The polar ${ }^{14} \mathrm{C}$ material $\left(R_{\mathrm{F}} 0-0.12\right.$ in system $\left.\mathrm{A}\right)$ was not further investigated in man, although this metabolite fraction in the rat seems to be a composite of debrisoquine and conjugated 4-hydroxydebrisoquine, 6-hydroxy-debrisoquine, a dihydroxylated metabolite and two carboxylic acids arising from oxidative ring scission (M.M. Angelo, L.G. Dring and R.L. Smith, unpublished observation). This polar band accounted for $3.9 \pm 4.7 \%$ ( \pm s.d.) $(0-11.2)$ of the dose.

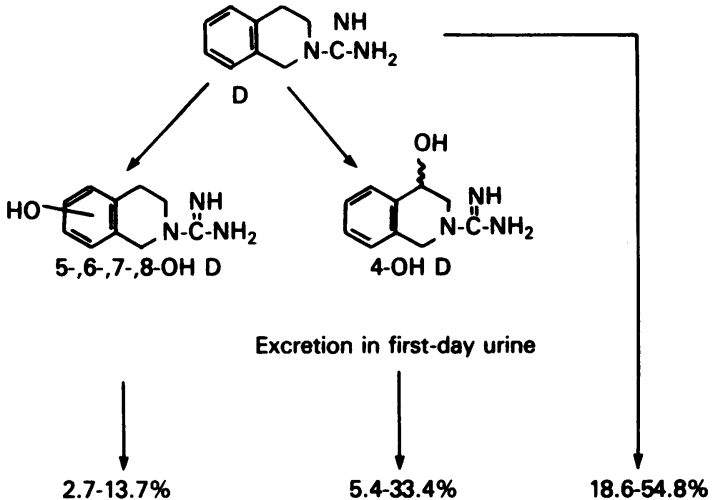

Figure 7 Pathways of oxidation of debrisoquine (D) in man.

\section{Discussion}

Debrisoquine, a strongly basic guanidine of pKa 12.5 , was well-absorbed when given orally and rapidly excreted by man. Greater than $70 \%$ of a dose of $32 \mathrm{mg}$ was found in the urine within $24 \mathrm{~h}$ and almost complete elimination (89-102\%) by urinary and faecal excretion occurred within 3 days. Debrisoquine and five monohydroxylated metabolites namely, 4-, 5-, 6-, 7- and 8-hydroxy-debrisoquine were identified and quantitated in the urine (see Figure 7). Except for a small amount of highly polar derivatives $(3.9 \pm 4.7 \%$, $n=7$ ), these metabolites accounted for all the ${ }^{14} \mathrm{C}$ eliminated in the first-day urine. Therefore, the two carboxylic acids which have been described by Allen et al. (1975, 1976), as urinary metabolites of debrisoquine must be minor metabolites comprising part of the polar unidentified fraction (vide supra).

Of the monohydroxylated metabolites, 4-hydroxydebrisoquine is clearly the major product, but its production is prone to a large inter-individual variation. By contrast, the four phenolic metabolites individually compose much smaller fractions of the excreted dose and show less inter-subject variability. Inter-individual variations in the extent of formation of 4-hydroxy-debrisoquine have subsequently been found to be genetic in origin (Mahgoub et al., 1977). The major metabolic reaction of debrisoquine in vivo is hydroxylation of the saturated ring system in the 4position. It is of interest that this alicyclic carbon position is more susceptible to metabolic oxidation than the aromatic carbon centres. The alicyclic hydroxylation of debrisoquine in the 4-position introduces a chiral centre into the molecule so that 4hydroxy-debrisoquine could exist in the $R$ or $S$ forms as well as the racemate. The nature of the hydroxylation of debrisoquine in vivo has not yet been 
ascertained but quite probably it involves a stereospecific mechanism, giving rise to all or a preponderance of one of the enantiomers as is known to occur in the hydroxylation of other compounds such as ethylbenzene (McMahon, Sullivan, Craig \& Pereira, 1969) and indan (Billings, Sullivan \& McMahon, 1970) (for review, Jenner \& Testa, 1973).

Apparently, the guanidine moiety is metabolically stable in man. Neither the urea analogue nor the $N$ hydroxylated metabolite was detected. This is in accord with the general observation that with guanidine-based drugs such as guanoxan (Jack, Stenlake \& Templeton, 1972), guanethidine (McMartin \& Simpson, 1971), phenformin (Beckmann, 1968) and amiloride (Weiss, Hersey, Dujovne \& Bianchine, 1969) the guanidine nitrogens are metabolically inert.

It is interesting to propose that the alicyclic hydroxylation of debrisoquine in the 4-position and the aromatic hydroxylation in the 5-, 6-, 7- and 8positions (see Figure 7) may be effected by quite separate mechanisms. Classically, aromatic hydroxylation to yield phenols is considered to be mediated via arene oxide formation (see Jerina \& Daly, 1977 for a review) although there are singular exceptions such as the 6- and 7-hydroxylation of butamoxane [2(butylaminomethyl)-1,4-benzodioxane] by rat liver microsomes which proceeds by the direct insertion of oxygen without either an arene oxide or dihydrodiol intermediate (Murphy, Bernstein \& McMahon, 1974).

\section{References}

ALLEN, J.G., BROWN, A.N. \& MARTEN, T.R. (1976). Metabolism of debrisoquine sulphate in rat, dog and man. Xenobiotica, 6, 405-409.

ALLEN, J.G., EAST, P.B., FRANCIS, R.J. \& HAIGH, J.L. (1975). Metabolism of debrisoquine sulphate. Identification of some urinary metabolites in rat and man. Drug Metab. Dispos., 3, 332-337.

ANGELO, M., DRING, L.G., IDLE, J.R., LANCASTER, R., MAHGOUB, A. \& SMITH, R.L. (1977). Defective alicyclic hydroxylation of debrisoquine in man. Br. J. clin. Pharmac., 4, 725P.

ANGELO, M., DRING, L.G., LANCASTER, R., LATHAM, A \& SMITH, R.L. (1975). A correlation between the response to debrisoquine and the amount of unchanged drug excreted in the urine. Br. J. Pharmac., 55, 264P.

ATHANASSIADIS, D., CRANSTON, W.I., JUEL-JENSEN, B.E. \& OLIVER, D.O.(1966). Clinical observations on the effects of debrisoquine sulphate in patients with high blood pressure. Br. med. J., 2, 733-735.

ATLAS, S.A. \& NEBERT, D.W.(1977). Pharmacogenetics and human disease. In Drug metabolism from microbe to man, ed. Parke, D.V. \& Smith, R.L., pp. 393-430. London: Taylor \& Francis Ltd.

BAER, H.H. \& ACHMATOWICZ, B. (1964). Cyclizations of dialdehydes with nitromethane: XII, o-Phthalaldehyde.
The mechanism of alicyclic $C$-oxidation, however, remains largely an enigma; it is hard to visualize the involvement of such intermediates as arene oxides with saturated ring systems. One proposal would be that the aromatic and alicyclic hydroxylations involve different forms of cytochrome P450. Biphenyl, bromobenzene, $n$-hexane, benz[a]pyrene and testosterone are well documented examples of molecules where hydroxylation occurs at different sites in the structure, one mechanism mediated in vitro by a phenobarbitone-inducible (P450) and the other by a 3methyl-cholanthrene-inducible (P448) cytochrome system (Atlas \& Nebert, 1977).

Debrisoquine is a compound which produces five monohydroxylated metabolites in man which can readily be quantitated by electron-capture gas chromatography at the $\mathrm{pg}$ level: It remains to be seen whether or not debrisoquine will prove useful as an in vivo probe for differentiating possible multiple forms of cytochrome P450 and individual variations in their occurrence.

MMA was in receipt of a scholarship from the Joint Standing Committee of St Mary's Hospital. AM is grateful to the E.A.R. Educational Bureau for financial support. We thank the Wellcome Trust for a grant for inter-disciplinary research. We are also grateful to Roche Products Ltd, Welwyn Garden City for the gifts of debrisoquine and its metabolites, and also Pfizer Ltd, Sandwich, Kent for the gift of 7-methoxy-guanoxan.
J. Org. Chem., 29, 3180-3185.

BAMBERGER, E. \& DIECKMANN, W. (1893). Ueber das Tetrahydrur des Isochinolins. Ber. Dtsch. Chem. Ges., 26, 1205-1221.

BECKMANN, R. (1968). The fate of biguanides in man. Ann. N.Y. Acad. Sci., 148, 820-832.

BILLINGS, R.E., SULLIVAN, H.R. \& McMAHON, R.E.(1970). Oxidation of indan to indanol and indanone by the hepatic microsomal system. Biochemistry, 9, 1256-1260.

EDITORIAL (1966). New Hypotensive drug. Br. med. J., 2, 717-718.

ERDTMANSKY, P. \& GOEHL, T.J. (1975). Gas-liquid chromatographic electron capture determination of some monosubstituted guanido-containing drugs. Analyt. Chem., 47, 750-752.

GRAFF, S., ENGELMAN, M., GILLESPIE, H.B. \& GRAFF, A.M. (1951). Guanine in cancer. Cancer Res., 11, 388-392.

HOFMANN, E. \& WÜNSCH, A. (1958). Use of nitroprusside in paper chromatography. Naturwissensschaften, 45, 338.

IDLE, J.R., MAHGOUB, A., LANCASTER, R. \& SMITH, R.L. (1978). Hypotensive response to debrisoquine and hydroxylation phenotype. Life Sci., 22, 979-984. 
JACK, D.B., STENLAKE, J.B. \& TEMPLETON, R.(1972). The metabolism and excretion of guanoxan in man. Xenobiotica, 2, 35-43.

JENNER, P. \& TESTA, B. (1973). The influence of stereochemical factors on drug disposition. Drug Metab. Rev., 2, 117-184.

JERINA, D.M. \& DALY, J.W. (1977). Oxidation at carbon. In Drug metabolism from microbe to man, ed. Parke, D. V. \& Smith, R.L., pp. 13-32. London: Taylor \& Francis Ltd.

KITCHIN, A.H. \& TURNER, R.W.D. (1966). Studies on debrisoquine sulphate. Br. med.J., 2, 728-731.

MCMAHON, R.E., SULLIVAN, H.R., CRAIG, J.C. \& PEREIRA, W.E. JNR. (1969). The microsomal oxygenation of ethylbenzene: isotopic, stereochemical and induction studies. Arch. Biochem. Biophys., 132, 575-577.

McMARTIN, C. \& SIMPSON, P. (1971). The absorption and metabolism of guanethidine in hypertensive patients requiring different doses of the drug. Clin. Pharmac. Ther., 12, 73-77.

MAHGOUB, A., IDLE, J.R., DRING, L.G., LANCASTER, R. \& SMITH, R.L. (1977). Polymorphic hydroxylation of debrisoquine in man. Lancet, ii, 584-586.

MULÉ, S.J., BASTOS, M.L., JUKOFSKY, D. \& SAFFER, E. (1971). Routine identification of drugs of abuse in human urine: II, Development and application of the XAD-2 resin column method. J. Chromatogr., 63, 289-301.

MURPHY, P.J., BERSTEIN, J.R. \& MCMAHON, R.E. (1974).
The formation of catechols by consecutive hydroxylations: a study of the microsomal hydroxylation of butamoxane. Mol. Pharmac., 10, 634-639.

NAKAO, H., YURA, Y. \& ITO, M. (1966). A new route to 4hydroxyisoquinoline. Sankyo Kenkyusho Nempo, 18, 48-50.

SHEMYAKIN, M.M., OUCHINNIKOV, A. YU, VINOGRADOVA, E.I., FEIGINA, M. YU, KIRYUSHKIN, A.A., ALDANOVA, N.A., ALAKHOV, B. YU, LIPKIN, V.M. \& ROSINOV, B.V. (1967). Mass spectrometric determination of the amino acid sequence in argininecontaining peptides. Experientia, 23, 428-430.

VETTER-DIECHTL, H., VETTER, W., RICHTER, W. \& BIEMANN, K. (1968). Ein für massenspektrometrie und gas chromatographie geeignetes argininderivat. Experientia, 24, 340-341.

WEISS, P., HERSEY, R.M., DUJOVNE, C.A. \& BIANCHINE, J.R. (1969). Metabolism of amiloride hydrochloride in man. Clin. Pharmac. Ther., 10, 401-406.

WENNER, W. (1965). 1,2,3,4-Tetrahydroisoquinoline derivation with antihypertensive properties. J. med. Chem., 8, 125-126.

WICKSTRÖM, A. \& SALVESEN, B. (1952). The separation and identification of some sympathomimetic amines by paper partition chromatography. J. Pharm. Pharmac., 4, 631-635.

(Received May 3, 1978) 